\title{
女性肺扁平上皮癌に関する臨床病理学的検討
}

\section{A Clinicopathological Study on Female Squamous Cell Carcinoma of Lung}

中田昌男・清水信義・佐野由文・安藤陽夫・寺本 滋

\begin{abstract}
要旨：当科において1976年から1988年に経験した肺癌症例のうち女性扁平上皮癌27例について 検討した．肺扁平上皮癌の男女比は11.4：1であった．女性症例のうち15例 (55.6\%)は 非喫煙者で，大多数が喫煙歴を持つ男性症例とは対照的だった．また，末梢発生が77.8\% を占め, $36.9 \%$ の男性症例とは著しく異なった。ケラチンに対する 2 種類のモノクロ一 ナル抗体, 抗keraSE抗体と抗keraNSE抗体を用いて免疫組織化学的に比較検討したと ころ, 女性症例15例中11例 (73.3\%)がkeraNSE陽性であったのに対し，男性症例のそれ は15例中 5 例 $(33.3 \%)$ であった，以上より，女性扁平上皮癌は免疫組織化学的に男性症 例とは異なる性格を有していると推測された。
\end{abstract}

〔肺癌 $32(4) ： 475 \sim 479, \quad 1992$ 〕

Key words : Female squamous cell carcinoma, Immunohistochemical study, KeraSE,

KeraNSE

\section{はじめに}

扁平上皮癌は肺癌において最も頻度の高い組 織型の一つであり, その疫学的特徵として男性 に多く，契煙が発癌に関係していることがすで に明らかとなっている。けれども，その少数で ある女性の扁平上皮癌症例に注目してみると， 臨床的に男性症例とはかなり様相が異なってい る場合が多い.今回我々は女性扁平上皮癌症例 の臨床像における男性症例との違いを明らかに するとともに，免疫組織化学的に女性扁平上皮 癌について検討を加えてみた。

\section{対象および方法}

1976年から1988年までに岡山大学第 2 外科に おいて経験した肺癌875例のうち, 組織学的に診 断の確定した扁平上皮癌336例(全症例の $38.4 \%$ ) を対象とした (Table 1). 男性309例, 女 性27例で男女比は11.4：1であった。

岡山大学第 2 外科
これらの症例について，まず喫煙指数，発生 部位，予後などを比較した。さらに病理学的検 討として，ケラチンに対するモノクローナル抗 体である抗keratin-squamous epithelium抗体 (以下 keraSE) と抗 keratin - non - squamous epithelium抗体 (以下keraNSE) を用いて，女性 扁平上皮癌と無作為に選んだ男性扁平上皮癌を 染色し，その染色性について考察した。男性扁 平上皮癌は中枢型と末梢型をほぼ同数選出した。 染色は各症例のパラフィン包埋ブロックを約 3

Table 1. All patients of lung cancer.

\begin{tabular}{l|rr|c}
\hline \multicolumn{1}{r|}{ Sex } & Male(\%) & Female(\%) & Total \\
Histologic type & & & \\
\hline Squamous cell carcinoma & $309(92.0)$ & $27(8.0)$ & 336 \\
Adenocarcinoma & $224(54.6)$ & $186(45.4)$ & 410 \\
Small cell carcinoma & $53(85.5)$ & $9(14.5)$ & 62 \\
Large cell carcinoma & $30(85.7)$ & $5(14.3)$ & 35 \\
Others & & & 32 \\
\hline
\end{tabular}


$\mu に$ 薄切したうえに，一次抗体とし てkeraSEとkeraNSEを, 二次抗体 としてビオチン化抗マウス IgGヤギ 血清, 三次抗体としてAvidin Biotin complexを用いた。

\section{結 果}

\section{I. 年 齢}

女性扁平上皮癌症例の年齢分布は 33歳から78歳までで, 平均60.7歳で あった。これは男性扁平上皮癌の平 均63.8歳より若干若く, 女性腺癌の 60.8歳とほぼ同じだった。

\section{2. 喫煙指数}

女性症例では喫煙指数が 400 以上 の重喫煙者は 9 例 (33.3\%) しかなく, 400 未満が 3 例，非喫煙者が15例 (55.6\%)であった。これは大多数が 重喫煙者であった男性症例とは著し く異なった。受動喫煙に関しては， 詳細な病歴がとれていない症例が多 く，検討できなかった。

\section{3 . 発生部位}

男性症例は中枢型195例，末梢型 114例と中枢型が多いのに比し, 女性 症例は中枢型 6 例, 末梢型 21 例と末 梢型が $77.8 \%$ 占め, 特徵的であっ た。

\section{4. 治療および術後病期}

切除例が 20 例で, 非切除例は 7 例 であった。切除術式は末梢型が多いために葉切 が16例と最も多く, 二葉切が 3 例, 肺全摘が 1 例であった。術後病期は I 期11例, II 期 1 例, III A期 3 例，III B期 3 例，IV 期 2 例だった.

\section{5 . 予 後}

女性扁平上皮癌切除例 20 例と同時期における 女性腺癌挹よび男性扁平上皮癌の各切除例の生 存率をKaplan-Meier法を用いて比較した (Fig. 1).女性扁平上皮癌の 5 生率は $36.0 \%$ で, 女性 腺癌の $47.8 \%$ 上り悪く, 男性扁平上皮癌の $34.2 \%$ に近かったが, 各群間に有意差はなかっ た。さらに，男性扁平上皮癌を末梢型と中枢型
Fig. 1. Survival curve of female squamous cell carcinoma, compared with female adenocarcinoma and male squamous cell carcinoma.

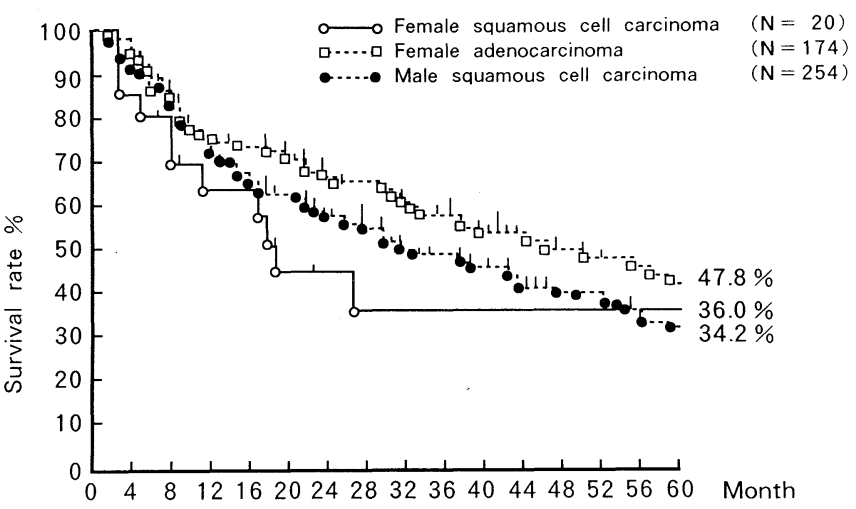

Fig. 2. Survival curve of female squamous cell carcinoma, compared with hilar type and peripheral type of male squamous cell carcinoma.

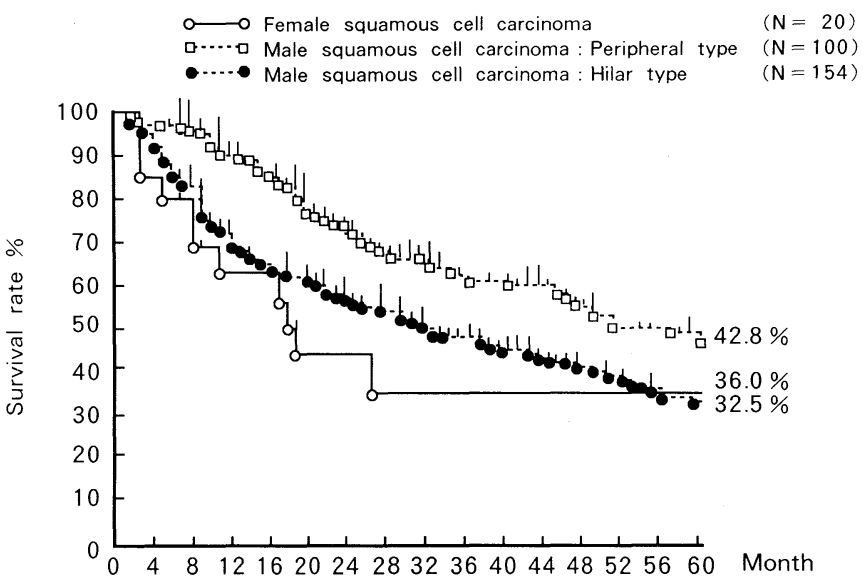

に分けて女性扁平上皮癌と比較すると，末梢型 男性扁平上皮癌は 5 生率 $42.8 \%$ と比較的良好で あったが, 中枢型は $32.5 \%$ と悪く，女性症例は その中間に位置した (Fig. 2).

また女性扁平上皮癌の予後を分化度別に検討 してみると，高分化型 6 例，中分化型 9 例のう ち I 期症例 8 例は 1 例を除いて生存しているが, 低分化型の 5 例では I 期症例の 1 例のみが生存 中で他の I 期症例 2 例はいずれも血行性による 遠隔転移で 1 年以内に失った。

\section{6. 免疫組織化学的検討}

今回モノクローナル抗体として用いたker- 
Fig. 3. Female squamous cell carcinoma stained by anti-keraNSE antibody.

Positive staining (black) is present within the cytoplasm of the malignant cells.

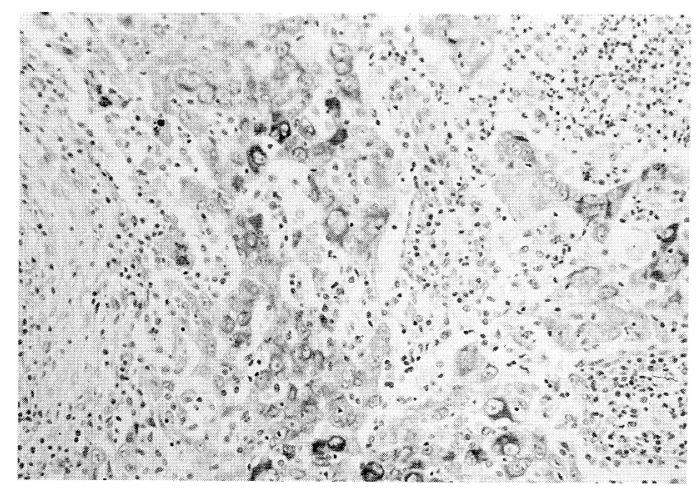

aSEは扁平上皮由来の分子量 $56 \mathrm{kd} ， 56.5 \mathrm{kd} ， 58$ $\mathrm{kd}, 68 \mathrm{kd}$ のケラチンに対する抗体で扁平上皮癌 に打いて陽性率が高く，一方，keraNSEは非扁 平上皮由来の分子量 $54 \mathrm{kd}$ のケラチンに対する 抗体で腺癌で陽性率が高いと言われている

結果はTable 2に示すようにkeraSEの陽性率 は女性症例が15例中 9 例 (60\%), 男性症例が14 例中 10 例 (71.4\%) で若下男性症例に多く，分化 度が高くなるにつれて陽性率が増加する傾向に あった。一方, keraNSEの陽性率は, 女性症例 が15例中11例 $(73.3 \%)$ と高率であったのに対し， 男性症例は15例中 5 例 (33.3\%) で，女性症例に 陽性率が高い傾向にあった (Fig. 3)。中枢型の 切除例が 1 例しかないため女性症例15例のうち 14例が木梢型であったが，末梢発生例だけで男 女比較をしてみても，女性症例では14例中10例 (71.4\%) が陽性であるのに対し，男性症例の陽 性は 8 例中 3 例 $(37.5 \%)$ でやはり女性に陽性率 が高かった。

\section{考 察}

扁平上皮癌は喫煙を主とする外的刺激によっ て比較的中枢の気管支上皮に異型をきたし発癌 すると考之られており，疫学的に男性に圧倒的 に多いのも，喫煙率の差によるものと考之られ てきた。けれども少数である女性症例に注目し てみると，必ずしも喫煙者ばかりではなく、今 回の結果ではむしろ非喫煙者が55.6\%占め,
Table 2. Positive rates by immunoperoxidase staining.

\begin{tabular}{l|cc}
\hline & keraSE & keraNSE \\
\hline Female & $9 / 15(60.0 \%)$ & $11 / 15(73.3 \%)$ \\
squamous cell carcinoma & $1 / 3$ & $2 / 3$ \\
$\quad$ poor diff. & $4 / 7$ & $4 / 7$ \\
moderately diff. & $4 / 5$ & $2 / 5$ \\
well diff. & $10 / 14(71.4 \%)$ & $5 / 15(33.3 \%)$ \\
Male & & \\
\hline
\end{tabular}

まな発生部位も末梢型が77.8\%で男性症例とは 大きく異なっていた。こ札らの相違点について

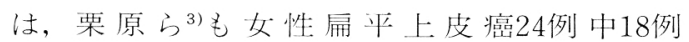
(75\%)が末梢発生であったと報告しており，

Sobueら ‘性症例でも契煙者は中枢発生が 多く, 非喫煙者は末梢発生が多いことを指摘し ている。こうしてみると, 女性の扁平上皮癌は 外的因子によって生じる扁平上皮癌とは異なっ な性格，考るいは発癌機序を有しているのでは ないかという疑問が生じる。女性肺癌の発癌因 子については, 受動喫煙を指摘する文献5),6), 家 族歴を指摘する文献》などが散見されるが，む ろん確定的なものはない。また，これらの仮説 はいずれも疫学的なものであり, 病理学的な検 討を加之たものは少ない。

そこで，我々は女性扁平上皮癌の性格を検討 する一手段として，ケラチンに対する 2 種類の モノクローナル抗体を用いて免疫組織化学的な 考察を試みた。ケラチンの分子量は40kdから67 $\mathrm{kd}$ に分布し, 屚平上皮癌では腺癌に比較して高 分子量のケラチンを含有している8 て, 分子量の異なる 2 種類のケラチンに対する モノクロー十ル抗体を用いて，元の陽性率を比 較すれば腫揘細胞の鑑別に役立つ。浜家ら よると, 扁平上皮癌に扮けるkeraSEの陽性率は 74\%であるのに対し，腺癌では $53 \%$ であり，ま た扁平上皮癌に抢汁る keraNSEの陽性率は

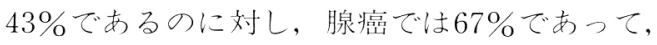
この 2 種類の抗体の組合せにより扁平上皮癌之 腺癌の鑑別が可能であるという。そこで女性扁 平上皮癌のうち15例と，無作為に選んだ男性嵋 平上皮癌15例をそれぞれこのふたつのモノクロ 
一ナル抗体で染色してみると, keraSEの陽性率 は男女間で差はなかったが，女性症例ではkeraNSEの陽性率が $73.3 \%$ と男性症例に比較して 高い傾向にあった，前述のごとく, keraNSEは 非扁平上皮由来のケラチンに親和性が強く, 腺 癌で陽性率が高いわけであるから，この結果は 女性症例の場合, 病理形態学的には扁平上皮癌 でありながら同時に非扁平上皮由来の細胞とし ての性格, 言いかえれば腺癌に似た性格をも合 わせ持っていることを意味している，今回の検 討では女性症例の大部分が末梢発生であったた め, その発生部位の偏りがこうした腺癌に似た 性格として表現されたのか，あるいはもともと 女性症例の場合腺癌に近い性格を有しているた め末梢発生が多いのかは断定できないが, 男性 症例では末梢型でも keraNSEの陽性率が低い ことから, やはり性差によってなんらかの違い があるのは確かである。また発癌機序について も，喫煙のような外的刺激だけでなく内的因子 の関与が大きいことも想像できる.

今回我々は, 女性扁平上皮癌の臨床像が男性 例とあまりに異なることに着目し, 病理組織学
的一面から検討を加之た．今回は症例が少数で あるので想像の域を出ないが, 今後さらに多く の症例を対象にし，また別の手段を用いて検討 すれば，女性扁平上皮癌の性格や発癌機序の解 明に役立つだけでなく，治療のうえでも寄与す るものと考える.

\section{結 語}

1. 女性扁平上皮癌症例 27 例を男性症例と比較 検討した。

2. 女性症例は末梢発生が $77.8 \%$ 占め，また 喫煙との関係は見られなかった。

3. keraSEの陽性率は性差がなかったが, keraNSEでは男性症例における陽性率が $33.3 \%$ で あったのに対し，女性症例では $73.3 \%$ と高率で あった。

4. 以上より, 女性扁平上皮癌には非扁平上皮 由来の細胞が高率に混在しており, 男性症例と は異なる性格や発生機序を有すると考えられた。

本論文の要旨は第 30 回日本肺癌学会総会 (平成元年 11 月，岡山ににおいて発表した。

\section{文 献}

1) Said JW, Nash G, Banks-Schlegel S, et al. : Keratin in human lung tumors. Patterns of localization of different-molecular-weight keratin proteins. Am J Pathol 113:27-32, 1983.

2）浜家一雄, 能瀬聰一郎, 星田義彦, 他: 肺癌打 よび胎児・成人の気管支上皮のケラチン陽性細 胞の検索. 岡山済生会総合病院雑誌, $21: 11$ $16,1989$.

3）栗原正英, 児玉哲郎, 亀谷 徹, 他: 非喫煙者 および女性の肺扁平上皮癌に関する研究. 肺 癌, $24: 263-272,1984$.

4) Sobue $T$, Suzuki T, Horai T, et al. : Relationship between cigarette smoking and histologic type of lung cancer, with special reference to sex difference. Jpn J Clin Oncol 18:3-13, 1988.
5) Shimizu H, Morishita M, Mizuno K, et al. : A case control study of lung cancer in nonsmoking women. Tohoku J exp Med 154 : 389-397, 1988.

6) Svensson C, Pershagen G, Klominek J : Smoking and passive smoking in relation to lung cancer in women. Acta Oncological $28: 623-629,1989$.

7) Horwitz RI, Smaldone LF, Viscoli CM : An ecogenetic hypothesis for lung cancer in women. Arch Intern Med 148:2609-2612, 1988.

8) Sieinski W, Dorsett B, Ioachim HL : Identification of prekeratin by immunofluorescence staining in the differential diagnosis of tumors. Human Pathology 12:452-458, 1981. 


\title{
A Clinicopathological Study on Female Squamous Cell Carcinoma of Lung
}

\author{
Masao Nakata, Nobuyoshi Shimizu, Yoshifumi Sano, \\ Akio Ando and Shigeru Teramoto
}

The Second Department of Surgery, Okayama University Medical School

A total of 27 cases of female squamous cell carcinoma of the lung from 1976 to 1988 were studied. The female-to-male ratio of the squamous cell carcinoma was $1: 11.4$.

There were 15 non-smokers among the female cases (55.6\%), however most male patients had a smoking history. The tumor site also showed a remarkable contrast between males and females, with $77.8 \%$ of female cases being peripheral type, compared with $36.9 \%$ of male cases.

An immunohistochemical study, using two types of antisera such as anti-keratin squamous epithelium antibody (keraSE) and anti-keratin nonsquamous epithelium antibody (keraNSE), was performed. In fifteen female cases, eleven (73.3\%) were positive for keraNSE, but only five $(33.3 \%$ ) were positive for keraNSE in fifteen male squamous cell carcinoma selected at random. This results suggested that female squamous cell carcinoma might have a different oncologic character from male cases. 